\title{
Fathers in a Coma: Father-Son Relationships in Neil Jordan's Fiction
}

\author{
Samuele Grassi \\ University of Florence, Italy
}

Copyright (c) 2008 by Samuele Grassi. This text may be archived and redistributed both in electronic form and in hard copy, provided that the author and journal are properly cited and no fee is charged for access.

\begin{abstract}
This paper will analyze father-son relationships in some of Neil Jordan's novels and short stories. His writing often deals with this theme, as well as with the gap between old and young generations. His works are often built around the contrast between tradition and modernity, such as de Valera's idealised concept of Nation and contemporary, 'global' Ireland. Thus following a consistent trend in contemporary Irish literature, Jordan develops new narratives of the Nation. What do fathers do? What do sons do? How do fathers respond to their sons' actions and behaviours, and vice versa? These questions will be addressed and, possibly, be answered. In Neil Jordan's work, father-son struggles have their counterpart in the process of the revision of ideologies and norms of tradition (patriarchy and the Catholic Church). At the same time, they are accompanied by a strong feeling of belonging to Ireland as a Nation.
\end{abstract}

Key Words. Father, son, Nation, de Valera, ghost, identity, roles.

Resumen. El artículo analizará las relaciones padre-hijo en algunas novelas y relatos de Neil Jordan. Su obra a menudo trata este tema, así como la distancia entre generaciones. Sus obras están construídas a menudo en torno al contraste entre tradición y modernidad, el concepto idealizado de la Nación propagado por de Valera y la Irlanda 'global' del presente. En sintonía con una arraigada tendencia de la literature irlandesa contemporánea, Jordan crea nuevas narrativas de la Nación. ¿Qué hacen los padres? ¿Qué hacen los hijos? ¿Cómo responden los padres a las acciones y comportamientos de sus hijos, y viceversa? Tales preguntas serán formuladas, y posiblemente respuestas. En la obra de Neil Jordan, las luchas padre-hijo tienen su contrapunto en el proceso de revisión d ideologías y normas tradicionales (patriarcado e Iglesia Católica). Al mismo tiempo, van acompañadas por un fuerte sentimiento de pertenencia a Irlanda como Nación.

Palabras clave. Padre, hijo, Nación, de Valera, fanstasma, identidad, roles.

During a conference in Munich in 1988 on the Irish cultural panorama, Richard Kearney asserted that: "Yes, we have an identity crisis in the South. But at least we are trying to work it out in our literature” (Kearney 1988b: 213). Kearney also pointed out that Ireland's "transitional crisis" must be viewed as a consequence of the country's move to globalisation, and this implied a reassessment of its national identity (Kearney 1988a: 84).
Irish contemporary authors, haunted by de Valera's ghost, have developed new narratives of the Nation in order both to re-gain possession of the concept of Irishness and of their own relationship with Ireland's colonial past and national history. The revision of traditional tropes and the shaping of alternative representations of individual and national identities lead to the deconstruction of stereotypes and 'typically Irish' re-workings of subjects and narrations silenced so far. It is in 
these borderline areas where everything new new forms of representation, new identities - is defined according to its obsessive relation with the past that Neil Jordan's work has its origins. A novelist, short story writer, screenwriter and director, Neil Jordan is perhaps the leading exponent of what Gerry Smyth has defined as the "Pan Celtic Revival" in Irish culture over the last three decades (Smyth 1997: 175).

At a superficial level, Jordan's techniques are similar to Flann O’Brien, Aidan Higgins and John Banville's postmodern deconstruction of narrative language, something which Kearney has referred to as a "counter-tradition" in Irish contemporary literature (see Kearney 1988c). These authors fluctuate in a mid-position between Modernism and revivalism, a position which Kearney has called "mediational Modernism ... a collage of modern and traditional motifs, ... It may be termed post-modern to the extent that it borrows freely from the idioms of both modernity and tradition, one moment endorsing a deconstruction of tradition, another reinventing and rewriting the stories of the past transmitted by cultural memory" (Kearney 1988c: 14). Neil Jordan's works, for instance, very often deal with the theme of father and son relationships set in the broader, metaphorical context of an attempt to leave behind the tradition established by Irish 'literary fathers'. His revision of traditional motifs and attitudes is motivated by the deconstruction of the norms and stereotypes of both patriarchy and the Catholic Church, which are currently being replaced by new identities that purport to cross boundaries as a means to undermine all stereotypes (of gender, of race, and of political ideals). A recurring theme in Jordan's fiction is also the rewriting of Irish myths of the Nation and an exploration of how these myths impinge upon people's lives and behaviour.

Some recent studies on Irish literature have drawn a comparison between Neil Jordan's point of view and Homi Bhabha's notion of third space (see Kearney, Smyth and Hopper). For Bhabha, hybridity does not account for the possibility "to trace two original moments from which a third one emerges, [but] (...) is the 'third space' which enables other positions to emerge. This third space displaces the histories that constitute it, and sets up new structures of authority, new political initiatives, which are inadequately understood through received wisdom” (Bhabha in Rutherford
1990). Neil Jordan's work moves freely within these ambiguous spaces, for it tends towards the indefinableness of all representations, in a never-ending process of revision of the possibilities of fiction. Kevin Rockett has appropriately defined certain tendencies in Jordan's fiction as a "trope of mutability", that is to say

(...) notions around appearance, reality and 'unreality', or the irrational; the psycho-sexual dynamics of the family, but most especially around the young male and the oedipal triangulation of desire; the interrelationship of private and public; the (im)possibility of transformation and the blurring of categories other than in negative terms; an enjoyment of the sensual, of fantasy and the impossible made possible ( $\mathrm{E}$ and $\mathrm{K}$ Rockett 2003: 1).

Father-son relationships are pivotal to the narrative development in many of Neil Jordan's texts (that is, the novels, especially The Past, The Dream of a Beast and Sunrise with Sea Monster, and some of the short stories in Night in Tunisia). It may be seen how the illuminating way in which father-son struggles are treated is linked to a common trend in Irish cultural debate - which had its peak in the 1990s - in which tradition is neither fully rejected, nor yet considered thoroughly reliable. In a time when Irish culture has been undergoing a radical re-structuring of its foundations, Jordan's work shows an urge for revision and invention of alternative representations of the narratives of the Nation. This is relevant for the study of contemporary Irish culture since his works belong to a genuinely post-modern (Irish) counter-tradition which focuses on transitional spaces, shifting deliberately across the United States and Europe, Ireland and England.

Neil Jordan's recent film production has over-shadowed his career as a writer and has perhaps distanced his interest in father-son and other traditional motifs and themes, as well as to issues of the Nation, which characterise his most accomplished works to date. However, below this choice there may lie his desire to leave the haunting ghost of the Nation's past behind once and for all; it is also possible that Rockett's definition of 'trope of mutability' could again provide an explanation, for it gives an eloquent judgment on Jordan's whole production. The analysis of a series of works in which the father-son struggles reach their climax will demonstrate how such an 'Irish' issue is still at the core of contemporary Irish 
literature. In spite of Ireland's move to globalisation and its recent economic-social developments, Jordan and most of his contemporaries share the same urge to mould ever-changing ideas of the Nation into their fiction, an urge which draws consistently on their revaluation of not only Ireland's, but also of their own past.

\section{A national myth of origins: The Past}

In his analysis of the epistemological crisis in post-modern Irish fiction, Neil Murphy has pointed out that, as much as Banville and Higgins, Neil Jordan responds to the lesson taught by Modernism, bringing his readers towards fictional worlds where human knowledge and experience are questioned (Murphy 2004: 3-4). Neil Jordan's first novel, The Past (1980) $)^{1}$ investigates the search for origins through a "richly metaphorical meditation on the interwoven concepts of nation and narration in Ireland" (Hopper 2001: 180 ). The unnamed protagonist is driven by the urge to unravel the truth about his parents' lives. In order to reach his purpose, he uses all that remains of his mother Rene, her pictures, and the memories of her longtime childood friend, Lili, an actress like her, and Father Beausang. The repeated use of "I imagine" from the very beginning of the novel, however, is a prelude to the disappointment of his expectations. Two key male characters in the novel, James and Luke Vance (themselves father and son), complicate the narrative even further. Every attempt at the truth is destined to be lost in the "musk of generation" (309) at the end of the novel. The plot raises the question of exile by introducing a portrait of Rene's parents', Una and Michael, who have to go to England to give birth to their "love-child" (8) conceived outside the bonds of marriage. Thus, they realize that they are "Irish, (...) carrying their cases, (...) whispering the confidence that they too are transplants to this imperial soil» (10). But they were also outsiders in Ireland, strangers in their own land, as there was no escape from the traditional family union as sanctioned by the Catholic Church's moral principles. Interestingly enough, Ireland here becomes "that country where there is only rumour and everybody is related” (18).

1. The Past, John Murray, London 2005: all bibliographical references in square brackets refer to this edition.
The ordinariness of the characters is juxtaposed with references to the fathers of the Nation and the characters' relationship with their own past. Jordan's writing habitually draws on events and personae from the history of Ireland. Eamon de Valera, for instance (in the novel, a friend of Una's), is portrayed as the national father par excellence. Here, he becomes "the gaunt schoolmaster ... his unlikely profile on the history of this place as surely as South American dictators stick theirs on coins and postage stamps" (50) (this is probably an intrusion by the writer himself, who questioned de Valera's presumed right to be the father of his Nation/Ireland in his 1996 film, Michael Collins). Rene's father is always evoked in the novel by his Free State Uniform. Having been killed during the Booterstown Seafront - where the Free State's Minister of Justice, Kevin O’Higgins, was murdered by IRA militants avenging some fellow republicans -, his death reminds readers of the way political violence breaks powerfully into the private sphere. In this novel, the private/public interaction is further stressed through the failed marriage of Michael and Una. James Vance, in a similar way, is characterised with his "sympathies Republican, his background Protestant. He has entered a Catholic marriage and his wife has not long ago died, having left him a son christened Luke.” (103). Religion and political commitment, it may be inferred, are dominant narratives written in the Nation's as well in individuals' histories. Kathleen Gallagher Winarski claimed that Jordan in his films extends his investigation of traditional Irish tropes, and shows that

(...) he is not intimidated by Irish tradition. Rather, Jordan explores Irish literature and culture as an artist who challenges tradition to express and to enrich his own vision, which is rooted in his past, but headed toward a future that will, by its nature, push the artist beyond all boundaries. For Jordan stretching the boundaries of tradition means liberating his fiction - breathing new life into Ireland's stories of family and nation through film and its ability to create intricate and subtle textures of characterisation and feeling. (Winarski 1999: 98)

Both Lili and Father Beausang recall the protagonist's parents' hidden past. It is Lili who helps Rene free herself from the burden of the Catholic education she has been subjected 
to by her mother, Una; it was also through Lili that Rene had discovered her sexual instincts, "And feeling Lili's hand (...) for such is the feeling welling inside you, you suspect it would fill a whole glass" (70) leading her to pass "from the age of innocence to the age of reason" (69). Father Beausang is James's best friend and little Luke's thoughtful mentor. Father and son live together with James's father, an elderly painter - just like Jordan's mother - as unable to break away from the memories of an impossible vision of the past as he is from his painting. Beausang is an ordinary local priest, himself a figuration of the male-oriented gender norms of the Catholic Church.

Beausang, above all, is unable to cope with personal relationships of any kind outside of his microcosm/the parish. His interest in the Vances may then be read as earnest commitment only because there is no woman in the Vance household fulfilling the traditional role of mother ${ }^{2}$. At a certain moment in the narrative, Beausang goes so far as to realise that "I loved that house (...) and its three generations of males and perhaps it was the fact that there was no woman there that enabled me to call so often (...) Was it this we shared, I wonder, this absence of femininity, because it often seemed that all our discussions in that sagging house concerned an absence which all three of them suspected might one day be filled" (187-8). Here may be seen not only evidence of the frankness of his attachment to that family but also hints of his veiled homosexual impulses.

In some parts of the novel the motif of father-son relationships is juxtaposed with a symbolic presence of fathers in a more general sense, a haunting presence influenced by the

2. Although the character of Father Beausang is not questioned further in the novel, there is a rather significant scene later on in which hints are given about his assumed homosexuality: "The yellow chair bumped to a halt and I was thrown forward into his lap. He held me for a moment by the shoulders and smiled. I could see the moisture gathering at the corner of each eye.” (213), which may represent a justification for the priest's odd attachment to the males of the Vance family. Also, when James visits his home his eyes are caught by a "lady (...) strangely male in her angular movements” (263). References to Catholic Church morals are frequently questioned by the author in his works. power of the arts evoked in the narrated events (painting, photography and acting). In these instances, the narrator's point of view shifts to reveal a continuum between father and son. A case in point is old Vance's rapture in front of his canvas "as if the brush is pulling his hand", with the strokes introducing the reader to James and Luke walking together ("His son was up the Head and his own son beyond him, near the crest”). This anticipates James's realization of the passing of time and of the sea of experience, as vast an ocean as that which he surveys with his son from the top of the crest: "death was not just like that sea, it was that sea and the only purpose of that sea was to remind him of his death" (137-8). Similarly, when James exhorts his son at the end of the novel not to repeat the same mistakes he has made, this takes place while old Vance dreams of them both as he sits by his canvas:

You must succeed where I failed. (...) You are my beloved son, he says, you must be everything I am not. But you made me, Luke says, turning his face around to the light. Luke shows the cut-out square of print to the old man, who proclaims it a masterful knee. I won't be with you much longer, the old man says, standing in the doorway. For a little while, then I won't be with you. You are my father, James says, you will always be with us. You made me. You made me, says Luke, turning again from the light. The old man shuffles back upstairs to where he mixes his pigments. Up there he dreams of them both, with his shock of white hair. (172-3)

As the protagonist is inspecting his father's and his father's father's house, the memories of the past are suddenly transformed into a compulsive quest for an identity - his own and what his eyes see is exactly what his nose smells and his inner self cannot resist ["He goes upstairs and urinates in the bowl, surrounded by the odour of fathers, of the slow drip across the years, of inheritance, colouring and temper, from father to son and father to son." (239)].

Another association is made between the myth of the individual and the myth of the Nation as the narrative setting shifts to Lisdoonvarna. Jordan enhances the metaphorical connotations of this episode by interposing a return to the origins of the 'national father', de Valera, ("Dev (...) the father of us all”, as Lily says). Looking for "that elusive elixir of abstentation politics and national health” (286), de Valera expects to 
receive from the holy waters that "extraordinary power" (300) necessary to be a good leader of a developing nation. This sort of parallel structure is a recurring device in most of Neil Jordan's fiction/works. Generally speaking, they pertain to a trend in contemporary Irish literature according to which the re-appropriation of the past as a category is a necessary step towards the development of new narratives of the Nation. Luke Gibbons has claimed that the same process can also be discerned in contemporary Irish cinema. And this would prove that the two forms of art share the same purposes, in contrast to the frequent conception that they are two different means of representation. Gibbons concludes that

(...) what is needed here is not less, but more attention to literature and film, for writers and film-makers in Ireland have already taken it upon themselves to question (...) omniscient or over-arching narratives. Some of the most distinctive - and, it could be argued, influential - strands in Irish fiction have sought to preempt the very possibility of the narrative coherence by introducing into fiction precisely the contingency of history - the chance event, the accidental detail, the unexpected encounter, the irrelevant aside (Gibbons 2003: 73).

In a 1982 interview, Neil Jordan ascribed the interest that led him to write The Past to his recollection of the day of de Valera's funeral:

\begin{abstract}
It was an extraordinary sight because it seemed to me that people didn't know how they should respond to this event. (...) And it seemed to me that it called for some response, it seemed to be an event that should gather a nation around it, like the death of Churchill in England or something as stupid as that. It seemed to symbolise to me the fact that Irish identity and the Irish consciousness was one of question and problems, not one of a firm knowledge of who and what we are. (...) and it also struck me that our inheritance is one of huge question marks all the time. (...) I suppose I was just wondering if human beings lose their memory of the past, whatever the significance it has for them. (...) all the influence that affects you seems to have nothing to do with a past that was seething with problems and was perhaps even a nut that couldn’t be cracked (Tóibín 1982: 16-7).
\end{abstract}

This would confirm the way Irish contemporary authors share the obsession for de Valera's ghost and the urge to confer thoroughly new interpretations to their own and their nation's past. As will be highlighted later in this study, autobiography plays a fundamental role in most of Neil Jordan's fiction. The obsession with the past as revealed in his first novel is something Jordan has more recently rejected, as if to confess that he has outgrown the topic and its ramifications.

\section{Impossible Fathers/Horrible Beasts: The Dream of a Beast}

Although Neil Jordan's second novel deals with issues of fathers much in the same way as the other novels considered in this study, there are some aspects in it which provide interesting and relevant variations; first, this novel features a daughter; and, the protagonist is haunted not by his own relationship with his father, but by his childood memories of his mother. The theme of the struggle father-son, as a result, overlaps with veiled references to an incestuous and to an oedipal relationship, though neither of the two is fully explicit anywhere in the novel.

The Dream of a Beast (1983) ${ }^{3}$ can be viewed as an Irish investigation of the fantastic and gothic genres. The plot follows the transformation of the protagonist into a beast. The definition used by Murphy to refer to Jordan's style seems fairly appropriate. He has spoken of him as a writer who frequently infuses his works with a genuine confusion of "Kafkesque dream visions with Blakean prophetic echoes” (Murphy 2004: 20).

In the beginning, a transformation takes place in the protagonist's surroundings, and he realises he is slowly being rejected by society ["Everyone was noticing things, remarking on things around them, but for me it was critical. Change and decay seemed to be the condition" (1)]. The protagonist's transformation mirrors that of Dublin, a city recognisable only through references to the names of the streets, and where the memory of an idealised past when things used to be different is pervasive: “... those buildings of concrete and glass that had come to litter the city, half-finished. (...) Spanning the wall behind was a miniature of the city as it once had been.” (87). It is now a violent place, with soldiers standing at every street corner. The way the city is portrayed is a reflection of how moral and social constrictions affect the development of an individual identity. Since, in this novel, the public sphere is the mirror of the private sphere, and vice versa, the pain suffered by the

3. The Dream of a Beast, Chatto \& Windus, London 1983: all bibliographical references in square brackets refer to this edition. 
protagonist is also due to the failure of his marriage to Marianne and his inability to perform the traditional role of father for his daughter, Matilde. In his commentary on The Company of Wolves (Jordan's 1984 adaptation of Angela Carter's short story), Kevin Rockett argued that in both that film and The Dream of $a$ Beast the author tries to underline the fact that "social fictions are (...) figured as subtle forms of ideological entrapment". According to Rockett, the novel is a meditation "about the possibility of transformation and finding acceptance and love, even within the constraints of the family (...) which draws on a number of issues - around the body, the family, alienation, transformation, difference, love”. Similarly, in the film The Miracle (1991), "the father is seen to fear that he cannot live up to the requirements demanded by his family" (Rockett 2003: 45-56). The violence in Dublin has its counterpart in the violence implicit in the domestic sphere, since the beast is betrayed by his wife who accuses him of incest. In this way, Marianne represents a deconstruction of the stereotype of women as protectors of the home and family cohesion. It is she who has fun with their friends, and who sends her husband away. The marriage is definitely over when she sends him away from the family home:

Don't come up, she pleaded, Matilde's not asleep. Please, my darling, I said, but the words sounded like heavy drops of oil, don't be afraid. I want to kiss her goodnight. I would have said more but I could feel her fear rush down the stairs towards me like a wall of water. I could by no means blame her, but that fear served to goad me even more. (...) Say goodnight from the doorway, she said. (...) I heard no reply. I drew as quiet and deep a breath as I could and began again. Before I reached the first consonant, however, I felt a blow from behind. The metallic pikes scraped me like a claw, I fell headlong, I heard a door slam and a key turn in a lock with a short reverberant click. (46-7)

Once again, the theme of exile functions as a means to escape gender roles and conventions, for the beast is also aware that "what is seen of him by others is not what he knows to be the truth but a mask". It is not a coincidence, then, that his transformation into a beast is now completed: "I gathered myself on to all fours. (...) I raised my weighty palm to that door and gouged some words on the cedar. Goodbye." (56-7). All that is left to him is the chance to resume his relationship with his daughter later in life. And it will only happen in his dreams, in one of which Matilde has grown up and admits that she is in love with him.

The beast's pain is lessened by his encounter with the "boy" - he, too, exiled, and a victim of violence - who also considers the beast's way of appearing as a way of displaying a notion of truth. Lori Rogers has referred to this as the "body-secret", which allows for a reading of the novel in terms of the truth being hidden in the deconstructive power of the secrets themselves. Rogers has also argued that

Politics, race, sexuality and national identities are merely social constructs, designed to be divisive, which, as Jordan states, impinge on the journey from seemin reality (the loathsome surface) to seeming unreality (the joy of inner reality). (...) If one's identity is performance even to oneself, Jordan is fully negating biology as intrinsic to the self at the same time that he sets up physiological change and internal bodysecrets as prerequisites for truth (Rogers 1997: 53-4).

While for the protagonist issues of violence and social constrictions (the performing of the traditional role of father, the soldiers on duty in Dublin) influence the shaping of his individual identity, and he responds to them by changing into a beast, for the "boy", on the other hand, violence is a product of his relationship with his father, who has him working hard all day and all night ["He was goaded on by shouts, coarse and violent. Then a dark-skinned figure in dungarees appeared, shovelled furiously with him for a moment, sent him spinning towards the furnace with a blow and left again, admonishing him to work faster" (76)].

According to what has been said so far, it is possible to read the water at the end of the novel as a metaphor for the beast's attempt to return to his mother's womb. No explicit mention of a mother-son relationship is made in the novel. But the protagonist does meet his mother twice in Dublin, though he neither greets her nor talks to her, for he is stuck in the memories of what has been lost forever and cannot be recovered: "My weekly visits had become an embarrassment. (...) I thought of how she must have missed me. In one full moment I felt how much I had missed her. My longing to touch her seemed to fill the carriage like a soaking cloud, like steam.” (24). Rockett has focused on this element in his analysis of the sea imagery in some of Neil Jordan's works. The sea represents a pre-natal condition, in that "To varying degrees, water 
and seaside are treated as the mise-en-scene of desire and sexual liberation, so that it becomes a metaphor for the ultimate desire, which is to return to the maternal waters and total plenitude" (E. and K. Rockett 2003: 109). The end of the novel is a case in point. Through the suppression of the possibility of an incestuous relationship with his daughter, and an unnameable bond with his mother, the beast can recuperate his pre-natal state and so end his spiritual wandering.

\section{The nature of betrayal: Sunrise with Sea Monster}

An enduring father-son struggle and the ways and means by which it both affects and mirrors political divisions are the main theme of Jordan's most accomplished novel, Sunrise with Sea Monster ${ }^{4}$. Hedwig Schwall places the text in a "'Robinsonian' trend in Irish literature", a mixture of historical novel and Bildungsroman which can also be found in Roddy Doyle's A Star Called Henry (1999), Glenn Patterson's Burning Your Own (1988), Seamus Deane's Reading in the Dark (1996) and Frank McCourt's Angela's Ashes (1996) (Schwall 2002: 31). Jordan's third novel consists of a set of sub-textual relations which complicate the father-son relationship and place it in the context of a rewriting of traditional Irish myths. Once again, the sea metaphor is dealt with. The sea is, primarily, where the protagonist, Donal Gore, can regain possession of his own past, marked by his mother's death when he was a child ("if she was gone anywhere it was into that sea" (12)). On the other hand, the sea substitutes the silence that characterises Donal's relationship with his father, Sam. Nature and the effects of silence have been focused on by Bernard Cardin in his recent study on the father-son relationship in some important contemporary Irish novels. As Cardin points out, silence in Irish literature dates back to Joyce's Dubliners where it is seen as "une forme de résistance (...) combat silencieux, signe d'insoumission à la volonté paternelle. C'est comme si le père avait tellement monopolisé la parole qu'il n'arrivait plus à la transmettre" (Cardin 2005: 78).

4. Sunrise with Sea Monster, Bloomsbury Publishing, London/New York 2004: all bibliographical references in square brackets refer to this edition.
In Sunrise with Sea Monster, the silence is twofold - on the one hand, it reveals an impossible relationship, an impossible affection which is always associated, in Donal's mind, with the positive memory of his father and himself while out fishing; ${ }^{5}$ when silence was more important than any speech. As Donal recounts to his prison officers, "This practice to be indulged in at arbitrary intervals with a familiar who may relish the sense of relative peace it brings, the main pleasure, I might add, being in the silence brought about by the absence of the need for speech.»" (63). On the other hand, Donal's childhood memories trouble him, since they remind him of his mother's death. They also remind him of Rose, and she becomes the pretext for the motif of father-son betrayal throughout the novel. Father and son both fall in love with her, and every 'family scene' is marked by the silence among the three of them ["the silence that seemed the natural state of things continued. / I maintained my silence. / (...) then walked in silence with him home.” (53)].

The plot is set at the time of World War II and the conflicts between Republicans and Free State supporters in Ireland. Donal Gore, a Republican/IRA sympathizer, joins the cause of the Republic in the Spanish Civil War but is soon arrested and jailed $^{6}$. He and his generation of rebellious sons consider every action as a means to betray the memory of 'fathers': "I came here because of all courses of action I could have taken it was the only one I knew with certainty that my father would have disapproved of." (19).

This novel also highlights the special role given to music in Jordan's work (see Angel, Night in Tunisia, The Miracle). In the novel there is a triangular relationship between Donal, Sam and Rose, Donal's piano teacher. The piano is all that is left to Donal of his mother. In the same way Sam seems to fall in

5. Father and son sharing the pleasures of fishing together as the only moment in which all conflicts are resolved is also a theme in Brian Friel's Philadelphia, Here I Come! (1964).

6. The Spanish Civil War features also in Colm Tóibín's The South (1990). In his The Heather Blazing (1992), moreover, the protagonist's father is paralysed after a stroke, just like Samuel Gore. The father in Tóibín's novel is also a public character, which may lead one to think that, as in Jordan's novel, a double mutilation takes place. 
love with Rose only because she plays the same tunes his wife used to play. Samuel Gore is a typical drunken father; he is unable to cope with life and running a family unless he has by his side a woman performing the traditional role of mother - the figure of Mother Ireland being her cultural projection - ["We'll make do, he said, won't we? And there was that hint of uncertainty in his voice, as if maybe we wouldn't. We will, I said and felt resentful at being the one who must provide the reassurance.” (11)]. Furthermore, the contrast between Spain and Ireland mirrors the fatherson divisions. The latter conflict also resembles the juxtaposition of Ireland and England as colonized/colonizer. Donal and his fellow Republicans regard their fathers as traitors to the Irish cause for having supported the Free State, and thus in part allying themselves with the colonizer. Betrayal as a leitmotif implies a betrayal of fathers, a betrayal of sons, and a betrayal of each other's causes. Donal feels his father has betrayed Ireland, so he betrays him; then, both of them betray the other and their mother/wife by falling in love with Rose.

A rhetoric of betrayal is established and is maintained by reiterated acts of betrayal. In addition, Donal's reflection on his acts of betrayal offers a clear explanation of the leitmotif at the core of Sunrise with Sea Monster: "Maybe the sins of fathers are visited on their sons." (62). What may be stressed is that by betraying the enemy (England), Donal also betrays his father and by 'betraying' Ireland, Sam betrays Donal. However, neither of the two can account for their choices and behaviour towards the other. Nor can they tell which act of betrayal is most inevitable. As a son, Donal is aware of his having achieved all that is expected of any son of the Nation/Ireland, and that it is something written in his nature as in everyone else's: "I can see myself as Judas, he who betrays because he dimly perceives that was all that was expected of him."; in other words, he belonged to a people who "having exhausted the litany of betrayal at home, sought new possibilities abroad." (16). At the end of this Chinese boxnarrative, Donal will finally acknowledge his inability to perform any action unless it implies an act of betrayal ["Who are you betraying? (...) / Just about everyone, I said. (...)” (123)] (Moller 2000: 7-8).

Donal's return to Ireland follows his father's stroke, which leaves him with no power of speech. This situation brings forth a new state of mind - since his father is no longer able to speak, Donal no longer suffers from the silence between them. The father's "castration", as Cardin has called it, deprives him of the threatening power he formerly exercised upon Donal. This event, Cardin underlines, relates back to a 'tradition' of castrated fathers in Irish literature represented most clearly in some works of Synge, O'Casey, Joyce and Beckett:

Tout lien symbolique est impossible car un lien diabolique s'interpose. C’est précisément parce qu'en raison de sa tétraplégie, Samuel Gore ne peut plus jouer son rôle d'interdicteur, parce qu'il ressent chez son fils de désir de le tuer et parce qu'il sait que ce dernier transgresse la loi en mettant la seconde épouse de son père dans son lit qu'il incite le narrateur à réaliser ses désirs jusqu'au bout ... Du reste, à l'instar du vieux Mahon de la pièce de Synge ou des mâles estropiés de O’Casey et de Beckett, les mutilations du corps paternel sont symptomatiques de ses nombreuses carences. Ces pseudo-héros que sont les géniteurs se voient singulièrement faibles, ou plus exactement affaiblis, terrassés par la maladie ou la vieillesse (Cardin 2005: 104-114).

Paradoxically, Sam's metaphoric castration makes it possible for him to enjoy a new emotional bond with his son. Nonetheless, this possibility exists only by virtue of the 'castration' it requires. This castration designates Donal to a relationship no longer based on silence ["And I think as I walk that it is strangely comforting to be with him and not have to listen. To have him beyond all argument. The wind rises a little and whips his scarf backwards so it strokes my face. And that is all the contact I need.” (89)]. Moreover, the new state of mind leads to an unpaired domesticity, with a reversal of the father's and son's roles. Sam is like a "great immobile child" (101); Donal is the household master. The repetition of the term "child" enhances the reversal of roles: "He'll sleep now. / How can you tell? / He has his habits, like any child. Help me." (109). / "Like a child, it seemed, each new turn of the rails intimated a different world." (116) / "like a child ... as the child he seemed to be." (129) / "He was like a child between us, following our movements with his eyes, waiting on our ministrations" / "He seemed sweet, like a child that completed our presence, the child we didn't have." (130-1). So does the use of the adjective "familiar" (which in Jordan's use seems to mean either 'habitual' or/and 'familial' in a number of 
warped reflection of one, but at least a family. (...) his now familiar dinner of smoked mackerel"), underlining Donal's renewed possibility of enjoying the pleasures of the home. Even more contradictory is the fact that the family as an institution is no longer viewed as a cage as it had been before.

Again, Lisdoonvarna is the mythical 'returnto-origins' site. Here, Donal's father disappears into the sea - an event which may either be interpreted as a miracle performed by the water or as the fulfilment of his suicidal tendencies, for he knows there is no room for him in the 'new family'. Having lost his father, Donal cannot contribute to the creation of a quiet family life with Rose. It is as if their mutual love had been strengthened by Donal's betrayal of his father. And because he also cannot leave his own past behind, he revives his and his father's practice of laying fishing nightlines: "Some days (...) I would look at the catch, see the dark shape of a porbeagle or dolphin among the slapping silver and imagine for a moment that I had caught him, his body having made the long journey home, the way salmon do" (175) (see also Cardin 2005). The sea monster at the end of the novel is a mythical revision with fantastic and surreal connotations. The monster is "outsize and majestic ... outlandish"; after it, Donal's father emerges out of the water, "Through the accident of fishing, I had brought him back, I knew, from whatever place he had inhabited." (186). Such an ending seems yet again to stress the theme of reconciliation which characterises Jordan's most accomplished fiction.

\section{Father-son struggles in Night in Tunisia and Other Stories}

Any analysis of Neil Jordan's short stories must take into account his role within the traditional Irish literary genre par excellence. Joyce's legacy (in Dubliners) to the contemporary short story in Ireland is something every contemporary Irish author writing short-stories must face and come to terms with. Jordan and his contemporaries have somehow had to cope with that. Facing the traditional genre may have been doubly hard for them, as it implies facing both their literary fathers and their own fiction. Cardin has examined how Joyce relates to issues of fatherhood in the Irish literary tradition:

Joyce serait, en quelque sorte, l'initiateur de la révolte du narrateur contre son père dans le roman d'initiation irlandais et donc le 'père littéraire' des jeunes auteurs contemporains. Cet héritage littéraire est parfois pesant pour la jeune génération, dans la mesure où il lui est difficile de trouver sa singularité, de se démarquer de ses prédécesseurs. (Cardin 2005: 164).

A Night in Tunisia and Other Stories was first published in 1976 and later re-issued after it was awarded the "Guardian Fiction Prize" in 1979. Jordan's stories are full of autobiographical references. In an interview he gave to an Irish public soon after his decision to start a parallel career as director and screenwriter, he pointed out that

The stories in 'Night in Tunisia' are all autobiographical, not in the sense of people I knew, or events that happened, but they're strictly photo-realistic. I found that I began to write inventive stories, fiction, but I could never write about people I knew, and I could rarely use the first person singular, the word ' $\mathrm{I}$ '. But I almost always had to describe something that I had seen (Toíbín 1982: 14).

Textual and visual elements overlap in Night in Tunisia ${ }^{7}$. The main theme is sexual discovery in the early teens. Most of the stories are set in Dublin and its surroundings, especially the local bathing towns such as Bray (where the author still lives today). Father-son relationships are another recurring theme in the collection. However, the theme is subjected to rather different and often contradictory alternative representations as compared to Jordan's later literary and film productions. The father-son private sphere, on the other hand, is always characterised by de Valera's ghost as a representation of the father of the whole Nation.

"Mr Solomon Wept" is the story of an archetypal, middle-aged and unattractive drunken father unable to cope with his young son or to understand or respond to social changes that have been taking place around him. His wife has left him for another, presumably younger, man: "He remembered how his wife had left him on race day, one year ago. (...) How on the fourth day he had gone to the caravan behind the rifle-range and found it empty, a note on the flap table. Its message was hardly legible, though simple. Gone with Chas. Won't have to hate you any more.” (34-5)

7. Night in Tunisia, Bloomsbury, London 2004: all bibliographical references in square brackets refer to this edition. 
Interestingly enough, his loss suddenly turns to "the loss of what he had never possessed" (35). The failure of all marriage relationships introduced in this and other texts by Jordan may then be read as a prelude to the need for a re-assessment of social structures in a global context, like Ireland during the 1970s-1980s. $\mathrm{Mr}$ Solomon spends all his days drinking whiskey and as victim of his son's disrespectful behaviour:

He could only stare, at (...) his thin impenetrable face. At his son's face, new to him because he'd never seen it. He made to move towards him, only then realising how drunk he was. He saw the boy's hand draw back and an object fly from it. He raised his hand to protect his face and felt something strike his knuckles. He heard the coin ring off the cement floor and the boy's footsteps running towards the door. He ran after him drunkenly, shouting. (39-40)

During a fair held on the beach, he is forced to realise that he has failed in all respects as a father. The story closes on his stumbling drunkenly on the beach, then falling face down on the sand only to hear his son laughing pitifully at him from a distance: "He lifted his face and wept in the sand ... He heard a loud cheer, somewhere beyond him" (41).

Jordan's treatment of imperfect father-son relationships in "Night in Tunisia" and "A Love" is even more extreme. "Night in Tunisia" is set in the countryside around the River Boyne (the setting of Jordan's last novel, Shade, published in 2005). The story is about an adolescent and his love for a grown-up girl who is rumoured by the townspeople to be a prostitute. Both of them have a drunken father. But, the protagonist's father is an amateur saxophonist whose main ambition is to play with friends in a local bar. His hatred for new musical tendencies grows with his realisation that he cannot really cope with them: "there was no more place for brassmen like him in the world of three-chord showbands. (...) the alto saxophone which his father said he could learn when he forgot his fascination for three-chord ditties. With the guitar which he played a lot, as if in spite against the alto saxophone.” (44). Again, the influence of music - which Jordan explores extensively in his first feature film, Angel - is questioned. In this case, the father makes great efforts to teach his son to play the saxophone; by contrast, the son spends his whole days listening to the same music his father hates: "But he felt vengeful and played (it) incessantly and even sang the tawdry lyrics
Some day soon, he sang, I'm going to tell the Moon about the crying game. And maybe he'll explain, he sang." $(47)^{8}$. The father's ability to play the saxophone accounts for the son's achievement of sexual maturity later in the narrative. In other words, a symbolic passage of power takes place from father to son - and what is more, it is the son who takes possession of his father's power: "he fashioned his mouth round the reed till the sounds he made became like a power of speech, a speech that his mouth was the vehicle for but that sprang from the knot of his stomach, the crook of his leg. (...) He imagined childhood falling from him, coming off his palms like scales from a fish" (62-3). Such use of an instrument and its metaphoric connotations diverges significantly from what Jordan does in Angel. There, we are shown Danny's substitution of his saxophone with a gun to avenge Annie and his friend, both of whom brutally murdered. Thus, Danny picks up an instrument of terror (the gun) to assert his maleness (see Kearney 1988d). Whereas in "Night in Tunisia", the drunken father spends every day in bed waiting for the time to get up and go with his friends to the bar to play. Never does he lose sight of his instrument; he apparently loves it more than he loves his own son ["The boy he'd known lifelong, old and somewhat loved, but not like his Selmer, shining." (49)]. And, through the sound of the saxophone, he re-takes possession of the remnants of his power within the home, which in turn his son undermines. As the two of them listen together to a song, the father begs his son to one day play with him:

“If you'd let me teach you,” his father said,
“you'd be glad later on.” / “Then why not wait
till later on and teach me then.” / "Because
you're young, you're at the age. You'll never
learn as well as now, if you let me teach you.
You'll never feel things like you do now.” / He
began playing again in defiance and then
stopped. / "I'll pay you," his father said. (60)

Soon, the son grabs the saxophone and starts to play. His father approaches him and shows him how to place his fingers on the keys; this episode gives him a pleasure which is "tangible, cogent." (62) - for it reverberates

8. The line "Some day soon (...) I'm going to tell the Moon about the crying game" is a verse of the well-known soundtrack to The Crying Game. This may be a further reference to Jordan's attention to music in all his novels, short stories and films. 
with his father's realisation that his role is over and that he is now handing it down to his son.

The father-son contrast is mirrored by the relationship between old and young generations as the main theme of "A Love". "A Love" tells of two ex-lovers who meet again after a long time, importantly on the day of de Valera's funeral. At first, de Valera, a multifarious and often contradictory character is just "the president who had died" - this, at least, from the point of view of the young protagonist, Neil ${ }^{9}$. On one level, Jordan recounts Neil's love story with the woman, far older than himself; on the other, he strategically associates every moment of their relationship with a different memory each of them has of the hero: "I remember you talking about him and I thought of how we would have two different memories of him" (95). The memories, in turn, influence their attitudes towards life in general: for Neil, what is part of the past (his and the Nation's) must be left behind. In a later passage, he sees de Valera's picture and suddenly remembers about the time he spent in London. This was when he had voluntarily undergone 'exile' to escape the harshness of living in a country (Ireland) stuck in its own past:

I had no memory of him other than from photographs and then only a big nose and bulging eyes and spectacles but I knew you would be changed and I knew I was changed and I wanted to stop thinking about it (...) the man who had died, he had been the centre of the school textbooks, his angular face and his thirties collar and his fist raised in a gesture of defiance towards something out there, beyond the rim of the brown photograph, never defined. And I wondered whether I'd rather be out of step here or in step in London, where the passions are rational. (97)

Flashbacks of the love story alternate with those of the father-son conflict, and their sharing the love for the same woman. Neil remembers the ecstasy and rapture he felt in his bedroom with his former lover. But he finds it even more pleasurable to remember how great an ecstasy it was to know, then, that he was slowly, firmly taking possession of someone

9. A parallelism may be made between Neil as the story's protagonist and Neil Jordan himself, given the particular interest of the author for autobiographical references in his works. Nonetheless, no mention of this is given in any of Jordan's critical work or in his interviews. his father had struggled vainly to 'conquer'. He had won, "And all the time for me there was my father lying underneath, cold most likely, and awake and I wanted him to hear the beast I was creating with you, I wanted to hear it scratching, creaking through to him from above, for your body was like the woman he must have loved to have me (...) you could have been anyone's mother" (99). In a variation upon the reconciliation theme, Neil attempts something none of Jordan's 'sons' usually do: he tries to shoot his father. His father is locked in the bathroom - significantly, a situation where he is defenceless. The story ends with a variation on the sea metaphor common to all of Jordan's texts examined so far (probably, a further reference to the 'return to origins' motif). The sea anticipates Neil's recovery of his own past, followed by his realisation that "I (..) saw him for the first time not as my father who wrote equations on sheets of paper into the night and knew a lot about things like sea-shells but as someone young and agile who had the same yearning for you as I had." (110-11). This means that the theme of reconciliation has been accomplished once again and once and for all.

The memories of two different fathers Neil's and the Nation's (de Valera) - are exchanged until the moment when on glancing out of the window of a pub where he's been sitting with his ex-lover, Neil is struck by the way the national hero (and, maybe, all narratives of Ireland's past) appears to him in all his contradictions: "I felt I was watching an animal dying through the plate-glass window, an animal that was huge, murderous, contradictory and I looked up at your face,(...) again at he funeral of the man I didn't remember, the man you would have remembered." (102). If it is true that, as Neil's lover tells him, one cannot really understand Ireland unless they have ever journeyed to the West (105), it is also true that Neil, and his generation of 'youth of today', can consider de Valera's/the fathers' ghosts as multi-layered characters to be rejected. What is all the more important is that the sons can finally and clearly comprehend "the nation that was begun (...) by de Valera's notions of what Ireland should be.» (Winarski 1999: 103). This seems to be what Neil Jordan himself has come to acknowledge. My gratitude to John Gilbert and Christine
Richardson for their generous advice. 


\section{Works Cited}

Cardin, Bernard. 2005. Miroirs de la filiation. Parcours dans huit romans irlandais contemporains. Caen: Presses universitaires de Caen.

Gibbons, Luke. 2003. "Narratives of the Nation: Fact, Fiction and Irish Cinema”. Theorizing Ireland. Ed. C. Connolly. New York: Palgrave Macmillan. 69-75.

Graham, Colin. 2003. “Subalternity and Gender: Problems of Postcolonial Irishness”. Theorizing Ireland. Ed. C. Connolly. New York: Palgrave Macmillan. 150-159.

Jordan, Neil. 2004 (1976). Night in Tunisia. London/New York: Bloomsbury Publishing. . 2005 (1980). The Past. London: John Murray. . 1982. Angel. 1983. The Dream of a Beast. London: Chatto \& Windus. 1991. The Miracle. 2004 (1994). Sunrise with Sea Monster. London: Bloomsbury Publishing. 1996. Michael Collins.

Kearney, Richard. 1988a. Across the Frontiers: Ireland in the 1990s. Dublin: Wolfhound Press. 1988b. "A Round Table on a Changing Concept”. Irishness in a Changing Society. Ed. The Princess Grace Irish Library. Gerrard Cross: Colin Smythe. 210-226. 1988c. Transitions. Narratives in Modern Irish Culture, Manchester University Press.

Mikowski, Sylvie. 2004. Le roman irlandais contemporain. Caen: Presses univeristaires de Caen.

Möller, Karin. 2000. "Beast in the Barrier Zone: Transformations of Irish Politics, History and Myth in Neil Jordan’s Sunrise with Sea Monster”. Humanetten, 6. http://www.vxu.se [retrieved 11/12/07]

Murphy, Neil. 2004 Irish Fiction and Postmodern Doubt. An Analysis of the Epistemological Crisis in Modern Irish Fiction. Lewiston/Queenston/Lampeter: The Edwin Mellen Press.

Rockett, Emer and Kevin. 2003. Neil Jordan: Exploring Boundaries. Dublin: Liffey Press.

Rogers, Lori. 1997. “In Dreams Uncover'd: Neil Jordan, The Dream of a Beast, and the Body-Secret”. Critique: Studies in Contemporary Fiction, 39. 48-54.

Rutherford, Jonathan. 1990. "The Third Space. Interview with Homi Bhabha”. Identity: Community, Culture, Difference. London: Lawrence and Wishart. 207-221.

Schwall, Hedwig. 2002. "Fictions about Factions: An Analysis of Neil Jordan’s Sunrise with Sea Monster". North Irish Studies, 1. 31-50.

Smyth, Gerry. 1997. The Novel and the Nation. Studies in the New Irish Fiction. London: Pluto Press.

Tóibín, Colm. 1982. “The In Dublin Interview: Neil Jordan talks to Colm Tóibín”. In Dublin, 152. 29 April. 14-19.

Winarski, Katherine Gallagher. 1999. “Neil Jordan’s Miracle”. Contemporary Irish Cinema: from The Quiet Man to Dancing at Lughnasa. Ed. J. MacKillop. New York: Syracuse University Press. 98108. 